\title{
Innovation and Application Strategy of Traditional Folk Culture in Animation Industry
}

\author{
Jing Li \\ Department of Art and Crafts \\ Henan Economy and Trade Vocational College \\ Zhengzhou, China 450046
}

\begin{abstract}
Traditional folk culture is the suitable soil to nourish local animation industry. It is also contemporary historic task to develop traditional folk culture with the help of artistic form of animation and make two of them intergrowth and win-win in the combination. It is a good way of inheriting folk culture and innovating national animation by integrating traditional folk culture into the training program of animation major in colleges and universities and paying attention to cooperate and integrate with modern scientific technology, and fully developing the economic value of traditional folk culture. It's waiting for us to continue to try and do in-depth exploration
\end{abstract}

Keywords-folk culture; animation; inherit; innovate

\section{INTRODUCTION}

In modern life, animation is not only an artistic creation form, but also a media vehicle of cultural transmission. People are delighted to hear and see its popular artistic language and rich infection. In recent years, as one of the new cultural creative industries, animation industry develops rapidly under the support of national policy, and theoretical research related to animation industry has become a hot topic; meanwhile, as the intangible cultural heritage, folk culture also receives people's attention and the exploring road of innovating folk culture also ranks among hotspot of contemporary cultural research. Is there a symbiotic and winwin developing way between animation industry and folk culture since both of them are parts of culture and arts? China, as one of the great powers of world civilization, has profound cultural accumulation, but lots of precious folk culture resources remain to be fully developed and contemporary animation industry is also faced with serious challenges and excellent development opportunities. If we can seize the opportunity and actively integrate the quintessence of folk culture into animation creation, then traditional folk culture will be inherited and developed in a new way and animation industry will be enriched with national characteristics.

\section{VIGOROUSLY STRENGTHEN THE EDUCATIONAL}

COOPERATION BETWEEN TRADITIONAL FOLK CULTURE AND ANIMATION MAJOR IN COLLEGES AND UNIVERSITIES

Animation is a discipline that art and technique are highly combined. With the application of modern high technology in animation industry, animation is not cartoon creation and animation production in traditional sense any more, but forms entirety constituted by many links, including the creation of animation original works, design of animation image, production of animation products, director composition, marketing, research and development of derivative products. Different links have different requirements for the knowledge structure and technical ability of talents. The formation and popularization of cartoon works need the division of labor of different levels of talents, mainly includes animation creative talents, production talents, marketing talents and managerial and administrative personnel. At present, what animation industry lack of is not production talents but high level talents who can do animation creation, research and development, marketing and management; we are not short of animation works, but high-quality original animation works that can reflect national characteristics and show traditional culture. To solve these problems, except for attracting foreign excellent talents, the biggest challenge faced by us is that how Chinese colleges and universities cultivate qualified and applicable talents for their own animation industry.

Reviewing the current situation of contemporary folk culture again, it is observed that if we cannot actively protect and correctly develop it, folk culture will be away from us gradually. We should start from school education to attach importance to and inherit folk culture, especially the education of animation major in colleges and universities. Looking from the education system of animation talents, at present, our country has institutions of higher learning that set up animation major. In regard to specialty development and talents training mode, they are still at the stage of exploration and development, cultivating more talents in technical aspect and less in culture creativity aspect; because of insufficient teachers and hardware facilities, some colleges and universities lack culture edification and management guidance for students. Under this circumstance, exploring the innovation road of the integration of traditional folk culture and contemporary animation industry must adjust educational objectives and curriculum system of animation major in colleges and universities, integrate modeling idea, aesthetic concept and artistic spirit of folk culture into educational process, and strengthen the cooperation between folk culture and animation product 
development. In 2012, Ancient City of Wandering, the largescale series of animated movie, planned and produced by hundreds of high vocational colleges and famous cultural cities together, is a new exploration that colleges integrate folk culture into animation creation. In three years, this animated movie will successively invite one hundred colleges and universities that have set animation major, link one hundred local famous cultural city, use a travel story full of love to connect hundreds of cities together and show folk characteristics and cultural spirit of different cities and help people to recognize the value of traditional folk by using relaxing form of animation. Taking Zhanjiang Normal University as an example, it integrates the curriculum of folk culture and culture of Leizhou Zhanjiang into art and design specialty, analyze and apply "Dancing Lion", a folk performing activity, into the course of animation major, which has achieved great success. In 2014, the product of cartoon character, with dancing lion as the theme, designed by internal student in Suixi, the home of dancing lion, has caused heated debate. The images are vivid and affectionate to people and the developed products include many kinds, such as dolls, posters, animation roles, signs, binding and layout, making people see the new direction of traditional folk culture in the development of cultural industrialization.

To strengthen the educational cooperation between traditional folk culture and animation major in colleges and universities can not only bring new vitality for folk culture, but also change some educators' single artistic conception for animation, expand their understanding of animation industry, and make them correctly know the commercialization and market value of animation. Meanwhile, in educational cooperation, we should learn excellent educational methods and educational patterns of countries where the animation industry is more developed, such as America, Japan, research the relation between their animation education and market, and organize personnel to write local teaching materials suitable for animation education in our country. In the compilation of teaching materials, they should pay attention to strengthening the edification of traditional culture, organically connect traditional folk culture, new technique of animation artistic creation and new ideas of the development of animation derivative products together, and guide students of animation major to explore and research national culture in school education.

\section{ACTIVELY PROMOTE THE INTEGRATION AND CONNECTION OF TRADITIONAL FOLK CULTURE AND MODERN SCIENTIFIC TECHNOLOGY}

To integrate traditional folk culture into animation industry should be with the help of transmission platform and artistic form of modern animation as well as attach importance to the combination of folk culture and modern high technology. Folk culture originates from rustic folk,

\footnotetext{
(1) Integration of Folk Culture and Local Education[EB/OL]. Henan Cultural Industry Network, 2014-6-27[2014-12-20].

http://minsu.henanci.com/Pages/201462791140.shtml
}

most of which exists in remote area with underdeveloped economy. With rapid development of information society, accelerating changes of people's lifestyle and realm of spirit, traditional folk culture and lifestyle are disappearing gradually as well. What's more, because the inheritance of many folk cultures depends on original spread by hand and mouth, they are very easy to fade and be forgotten by people during the process of spread. Without development, it will lag behind. To let traditional folk culture conform to the aesthetic idea of modern society and be accepted and loved by modern people, we must use scientific and technical means and integrate modern elements, which can help folk culture to be better popularized and produce expected value.

Take "mud monkey Zhang" in Henan as an example, Zhang Xihe, the "mud monkey Zhang", is the inheritor of intangible cultural heritage of Henan province. He has been obsessed with clay sculpture art for 70 years and his ceramic craft is called "cartoon ceramic craft" by Mr. Shen Tongheng, a famous cartoonist. The mud monkeys made by him are in different shapes, flexible and vivid and he is praised as "mud monkey Zhang, a smart talent". But before cooperating with Zhengzhou Huaguan Animation Creativity Limited Company, such wonderful folk art hasn't been well-known. Because of loving the works of "mud monkey Zhang", after exploring its prospects, Zhengzhou Huaguan Animation Creativity Limited Company decides to take the company as a display platform for the works of "mud monkey Zhang", provide individual studio to Mr. Zhang and make monkeys of "mud monkey Zhang" into series of works, such as series of Journey to the West, family affection, and offering birthday congratulations, etc. Besides, it endows the works with a rich variety of implied meaning, makes customized specifications of cartoon forms for each series of works to tell stories of the works of "mud monkey Zhang" with images and texts. After achieving initial success, the company depends on the influence of traditional clay sculpture culture and launches a development platform to cultivate Children's diversification-Children's Arts Creative Center of "mud monkey Zhang". It carries forward and inherits folk clay sculpture culture, at the same time, advocates the learning concepts of "play with mud, find childlike innocence, grow up happily", which is popular with the children. In the second half of 2014, the company has started the creative production of large 3D TV animation series of "Magical Hand, Mud Monkey Zhang", being carried out in an orderly way currently.

From the above case, we can clearly realize that it is a feasible way of modern development to create folk culture by using cartoon form and animated virtual technology. Now we turn to early successful cases: in the 1960s, with the help of the form of animation, the animated movie of The Monkey King lets the world know Chinese masterwork of Journey to the West; at the beginning of 2004, the animated movie of Butterflies in Love also successfully and completely performs traditional folk tales; in August 2015, the domestic new animated movie of Monkey King: Hero is Back also draws materials from Journey to the West. The value of animation works not only lies in reflecting on the value of market economy, but also showing excellent traditional folk 
culture through these works. Of course, it's our primary task to open our thought to develop, let folk art and modern science and technology integrate and collide, industrialize folk culture and create a platform for intangible cultural industry and realize sustainable and healthy development for folk art, modern science and technology. ${ }^{2}$

\section{FUlly DEVEloP THE ECONOMIC VALUE OF TRADITIONAL FOLK CULTURE WITH THE HELP OF ANIMATION INDUSTRY}

Animation industry is the most representative and important part of cultural creative industry. Now, in the era of picture-reading, animation has become an effective and important carrier to spread contemporary culture. As a modern popular artistic form, animation has relaxed, humorous, vivid and human-readable characteristics which can easily attract the audience. These characters closely integrate it with traditional folk culture that has extensive penetrability, which is one of the effective methods to protect and carry forward excellent folk culture. Unfortunately, because our understanding of traditional folk culture in the past only rests on its cultural value, without sufficient understanding for its economic value, and we neglect the market development of folk culture, a lot of precious cultural treasures have become the sources of the wealth of others. Many animated movies made by America such as Mulan, Kung Fu Panda, and their derived works all use a large number of Chinese cultural elements as selling points ${ }^{3}$. When learning the painful lessons, we must fully develop the economic value of traditional folk culture at the present times with the help of the development of animation industry. Except for creating original cartoon images that have folk culture and national features, we should infuse the elements of folk culture in the development of animation derivatives and develop its huge commercial potential and economic value. In recent years, the key reasons of affecting the development of animation are that derivatives of cartoon images are under insufficient development and lack of complete industrial chain. Animation derivative is a very important factor of animation industry chain: on one hand, it can become important source of animation theme; on the other hand, it is the key to extend animation industry chain and the main source of profit of animation industry. To develop economic value of traditional folk culture, we can set about from the following aspects: firstly, consider national situations, fully consider audience factor, and confirm market requirements through rigorous market research and textural research, make animation derivative products combine with folk culture to develop timely and properly, and properly reflect national characteristics on the creation form, modeling features and color characteristics of

${ }^{2}$ Li Can. Huaguan Animation: Fully Promote the Integration of Traditional Culture with High Technology [EB/OL]. Henan Cultural Industry Network, 2014-9-1[2014-12-20].

http://www.henanci.com/Pages/2014/09/01/20140901103902.shtml

(3) Su Qing. Survival of Connecting Folk with Animation and Folk Derivation of Animation-Discussion on Industrialization Development of Culture Creativity in Combining Folk Culture and Cartoon Culture[EB/OL], Sina Blog, 2009-10-18[2014-12-20].

http://blog.sina.com.cn/s/blog_3e5335b10100f734.html derivatives. The types of derivatives can be not only material products such as audiovisual products, toys, stationery, costume and foods, but also products of spiritual entertainment. For example, we can imitate the operation mode of the Disney, combine games of traditional folk with large-scale parks, places of recreation, and famous scenic spots in various regions to develop games, entertainment and tourism projects, etc. Secondly, creating domestic cartoon stars with traditional images in folk culture as the carrier can reflect the characteristics of our domestic cartoon images, and propagandize folk culture with the help of imagebuilding of cartoon stars. Thirdly, build a professional operation team of folk animation. What's more, we should explore the development road to connect traditional folk culture with animation industry, try to create animation by different forms of artistic presentation and multimedia technology, and create, develop and promote the comic books, films and television programs about animation and derivatives related to folk culture to show value and connotation of traditional folk culture. In addition, we can fully develop the market value of traditional folk cultural products through the spread of digital new media such as film and television, internet and mobile phone network, push excellent folk cultures to the stage of world art, let more people know Chinese folk culture, set up the brand of the value of national folk culture then provide the creation and production of folk animation with strong financial support to realize virtuous circle of industrial chain..

\section{CONCLUSION}

Development is the fundamental principle. Development, transformation and innovation are the best methods to inherit and protect folk culture. Applying the innovation of connecting folk culture with animation to animation industry with the help of transmission platform and media vehicles of modern animation is not only a new opportunity to carry forward folk culture, but also a good way to develop animation industry. At present, animation industry in our country isn't very mature, but we have reasons to believe that through paying attention to and use folk culture, with the support of relevant institutions and enterprises and joint efforts of art educators, the perfection of animation industry will be realized before long. Chinese animation industry with characteristics of folk culture will be bound to show new flourish vitality and modern spirit.

\section{REFERENCES}

[1] Transmission Bottleneck and Difficulties of Chinese Animation on New Media Platform [EB/OL].CNANIME,2012-08-08[2014-1110].http://www.cccnews.com.cn/2012/0808/10347.shtml

[2] Li Shuang. Promoting Role of Animation Industry for Protection and Development of Folk Cultural Resources[J] Huazhang Magazine. 2012.06

[3] Ding Yan. Discussion on Application Research of Folk Culture in Animation Creation[J]. Popular Literature. 2013.12.

[4] Wang Dawei. Application Research of Traditional Visual Elements in Character Design of Animation[D] Xi'an: Xi'an University of Technology, 2008. 
[5] Su Qing. Survival of Connecting Folk with Animation and Folk Derivation of Animation-Discussion on Industrialization Development of Culture Creativity in Combining Folk Culture with Cartoon Culture[EB/OL], Sina Blog, 2009-10-18[2014-12-20].

[6] http://blog.sina.com.cn/s/blog_3e5335b10100f734.html 